RJOAS, 6(114), June 2021

DOI 10.18551/rjoas.2021-06.03

\title{
EFFORTS OF DRY-LAND FARMERS OF KANO-NIGERIA IN THE CONDITIONS OF COVID-19 PANDEMIC THAT HITS GLOBAL FOOD SECURITY
}

\author{
Salami Azeez Oyeniyi \\ Shelterbelt Research Station, Forestry Research Institute of Nigeria, Kano, Nigeria \\ E-mail: faunia717@yahoo.com \\ ORCID: 0000000282500898
}

\begin{abstract}
A survey was conducted in Kano State-Nigeria aimed at exploring the travails of the dry-land farmers of the state amidst Covid-19 pandemic lockdown. The exercise was carried out in 8 Local Government Areas marked out in two sampling units within the metropolis and outside the metropolis. Within the Kano metropolis were Nassarawa, Ungogo, Tarauni and Dala; while Madobi, Minjiibir, Garun Mallam and Dambatta were outside the metropolitan. The enumeration thus pointed to the complete halt of all activities in the state during the ill-fated lockdown which was coupled with hunger, starvation, alongside stringent survival strategies; difficult access to agricultural imputes aids; and the effects on farming activities, among others. Structured interview was employed with a total of 120 respondents, using Availability Sampling Technique. However, food insecurity and malnutrition in Nigeria is as a result of the non implementation of the national and conventional food policy and agricultural programs. Nonetheless, in this critical time of economic pressure and the insurgence of Covid-19 pandemic, it is very important therefore to improve the budget allocation to the agricultural sector, as well as sustainable agricultural policy improvement programs by giving very compelling priority for nutrition on the agenda of the government, and enforcing a vibrant policy at aiding these dry-land farmers from whom the bulk of the global food production emanates.
\end{abstract}

\section{KEY WORDS}

Travails, palliative measures, enumeration, starvation, food insecurity, sustainable.

Agriculture is yet the mainstay of Nigeria's economy, employing approximately $2 / 3$ of the country's total labour force, and contributing 40\% to its GDP. Nonetheless, Nigeria is the world's largest producer of cassava, yam, and cowpea, yet it is a food-deficit nation, and depends on imports of grains, livestock products, and fish. Moreover, of an estimated 71 million hectares of cultivable land, only half is currently used for farming. However, there is similar potential for an expansion of irrigation, but which now only covers $7 \%$ of the irrigable land. Most of the rural population farms on a subsistence scale, using small plots in view of small-holder farming system born out of perpetual family chain inheritance, and depending solely on seasonal rainfall. A lack of infrastructure such as roads further exacerbates poverty in the rural areas by isolating rural farmers from needed inputs and profitable markets (IFAD, 2012).

Apart from the above, pressure from growing populations is also impacting already diminished resources, further threatening food production and gluing insecurity. Over-farmed land, deforestation, and overgrazing are also very severe in many parts of the country, as charcoal and fuel wood utilization are officially allowed to sit tight in the energy consumption drive. However, drought has become common ecological problem in the north, while erosion and flooding is a major quandary in the southern part, which further reduce the strength of the peasant farmers to increased food insecurity (FSP, 2012).

As such, Nigeria is no doubt one of the food-deficit countries in Sub-Saharan Africa, although it is arguably better in terms of production than other countries in the region. It has also not suffered any major catastrophe that could precipitate scourges of famine, mass hunger, and 
therefore food crisis (Atinmo and Adeniran, 1999). However, the wide gap between intents and actual practices vis-à-vis Nigeria's food policy and programs may require a new approach and philosophy, if the fate that befell some of her neighbors will not befall the country, and more so that the country lacks clear cut food policy programs (FSP, 2012).

Additionally, according to an assessment of the challenges, information needs, and analytical capacity conducted by Akinyele (2009) on ensuring the food and nutrition security in rural Nigeria, it was observed that the country is still characterized by high reliance on food imports. Malnutrition is widespread in the entire nation, and rural areas are especially vulnerable to chronic food shortages, malnutrition, unbalanced nutrition, erratic food supply, poor quality foods, high food costs, and even total lack of food. This phenomenon cuts across all age groups and categories of individuals in the rural areas. Furthermore, there is a high level of malnutrition among children in rural Nigeria, and the figures differ with geopolitical zones, with $56 \%$ reported in a rural area of South West, and $84.3 \%$ in three rural communities in the northern part of Nigeria. Nationally, the overall prevalence of stunting, wasting, and underweight is $42.0 \%, 9 \%$ and $25 \%$ respectively according to Akinyele (2009) analysis.

Consequent to the above, it was further observed that the problem of food and nutrition security in Nigeria has not been adequately and critically analyzed despite various approaches towards addressing the challenges. Therefore, the enormous amount of money spent in attempting to assure the food security of Nigerians without success calls for a fundamental review of the past approaches and achievements to see what lessons can be learned so as to re-strategize and develop an approach that will ensure that better progress is made towards achieving the first Millennium Development Goal. Furthermore, since the majority of Nigerians $(70 \%)$ live in the rural areas, an analysis of the food and nutrition security status of rural dwellers will provide a clear picture of what needs to be done to assure food security in the country, with the attendant improvements in nutrition status, when all the other necessary conditions such as adequate health and care, are present (Akinyele, 2009).

Then like a flashlight, the Corona Virus Infectious Disease (Covid-19) came unexpectedly (adding more to the above mentioned calamities), killing people in thousands and overwhelming even the super powers of the world, and Nigeria specifically does not have enough tensile strength in their shock absorbers to insulate its citizenries as the global lockdown began. This took Nigeria in the gross to prolonged poverty, hunger and distress. Meanwhile, the tropical Africa was lucky that the manifestation was not severe in the region. As at $15^{\text {th }}$ August, 48,770 cases were just confirmed in Nigeria, with only 974 deaths amidst over 600,000 global deaths and more than 240,000 every 24 hours. Moreover, the United States of America (USA) was recording about 2,409 daily deaths around April $22^{\text {nd }} 2020$, which was yet not at the peak.

Kano State is a foremost agrarian community in Nigeria's dry-land. Beginning from Lagos, Ogun and the Federal Capital Territory (FCT) Abuja, Kano State was one of the first calls of Covid-19 pandemic and the subsequent lockdown. Additionally, the first index contact case to the Corona Virus infection in Kano was said to come from a 75 year old former ambassador of the Federal Republic of Nigeria on the $11^{\text {th }}$ of April, nearly two months after the country's first confirmed case on $27^{\text {th }}$ February through an Italian that came to Lagos. However, within a span of less than seven days, the infestation in Kano State had increased from 1 to 73, and the number of unexplained deaths increased from zero to 180 within four days. These spates of unexplained deaths recorded in Kano between March and April (fig. I), partly drove the urgency in the need for testing. On the $28^{\text {th }}$ April therefore, President Muhammadu Buhari ordered a lockdown in the state and deployed experts to assist the investigations into the cases. For months thereafter, confusion and conjecture surrounded the story of mass deaths in Kano State, northwestern Nigeria, which occurred in April, 2020 during the COVID-19 pandemic lockdown.

The first seven days of the lockdown in Kano was initiated by the state governor, Dr. Abdullahi Umar Ganduje, which began on the $16^{\text {th }}$ April to contain the outbreak of the novel 
Corona virus infection, before President Muhammadu Buhari ordered a fresh two weeks lockdown on the state from April $27^{\text {th }}$. It was further extended by another two weeks, and as at June $1^{\text {st }}$, Kano accounts for 954 out of the 10,162 Covid-19 cases in Nigeria (Egbunike, 2020).

After several weeks of speculation and official denial, on June 8, Nigeria's Health Minister confirmed that a surge of mysterious deaths recorded in Kano State was "triggered by or due to COVID-19." Dr. Ehanire further stated that Kano witnessed 979 deaths "at a rate of 43 deaths per day" in April. The deaths, within eight metropolitan local government areas of Kano State, affected people aged 65 and over, with pre-existing conditions according to Egbunike (2020).

Nonetheless, at the world food conference of 1974, food security was defined as the availability at all times of adequate, nourishing, diverse, balanced and moderate world food supplies of basic foodstuffs to sustain a steady expansion of food consumption, and to offset fluctuations in production and prices. Moreover, the final report of the World Food Summit of 1996 however stated that food security exists when all people at all times have physical and economic access to sufficient, safe and nutritious food to meet their dietary needs and food preferences for an active and healthy life (FAO, 1996; 2003). However, according to the United States Department of Agriculture (USDA), food insecurity is a situation of limited or uncertain availability of nutritionally adequate and safe foods, or limited or uncertain ability to acquire acceptable foods in socially acceptable ways as contained in Gary, et.al (2000).

This study hereby aimed at the evaluation of the travails of the dry-land farmers of KanoNigeria in the event of the Covid-19 pandemic lockdown against the global food production and security program.

Kano state is one of the largest Hausa states in Nigeria. It is located in the north-west geopolitical zone, with current population estimate of over 9 million people. Kano State occupies a land mass of about $20,131 \mathrm{Km}^{2}$, on an approximate latitude $11.76^{\circ} \mathrm{N}$, and longitude $8.66^{\circ} \mathrm{E}$. Rainfall is between May and October, but stable for about 4 months between June and September, approximately $510-1140 \mathrm{~mm}$. per annum. Relative humidity is low and temperature varies between $14^{\circ} \mathrm{C}$ and $38^{\circ} \mathrm{C}$, typical of Sudan savannah ecosystem. Over $80 \%$ of the populace is however engaged in subsistence farming and animal husbandry, the reason why the zone is considered agrarian, as majority of the working adults engage in agriculture as a means of livelihood (Salami, 2018).

\section{METHODS OF RESEARCH}

The survey was carried out within and outside the Kano metropolis during the confinement and when the structural ease out of the lockdown orchestrated from the Covid-19 pandemic commenced. Structured interview was used with a total of 120 respondents, 60 each from within and outside the metropolis which spread across the two sampling units randomly, using Availability Sampling Technique. Availability sampling is the same as accidental or convenience sampling. It is mostly used in the interview research method, and involves a situation where anyone seen or come across is interviewed (Asika, 2006). A total of 4 Local Government Areas (LGAs) were covered for each of the 2 sampling units, amounting to 8 LGAs in all. These were Nassarawa, Ungogo, Tarauni and Dala in the Kano metropolis; while Madobi, Minjiibir, Garun Mallam and Dambatta LGAs were covered outside the metropolitan. Sampling frames were however drawn simultaneously.

\section{RESULTS AND DISCUSSION}

Respondents were made to comment on the complete halt of all activities and access to their farms, exposure to hunger, starvation, and the survival strategies employed, as well as problems of access to agricultural imputes aids and assistance, inclusive of the Kano massive mortalities; and the various effects on their farming activities during the lockdown order, among 
others. It is however important to note that the initial phase of the lockdown coincided with the beginning of the dry season farming, and running across the main season.

Respondent reports unanimously inclined that the lockdown order in view of the Covid-19 pandemic had a very devastating effects on the activities of the dry-land farmers of Kano State. The first seven days of the lockdown began on the $16^{\text {th }}$ April, 2020, in a bid to contain the outbreak of the novel Corona virus infection, as the catastrophe had started manifesting rudely thereupon, before President Muhammadu Buhari ordered another two week follow up process on the state from April $27^{\text {th }}$. It was further extended by another two weeks, and as at June $1^{\text {st }}$, Kano accounts for 954 out of the 10,162 Covid-19 cases in Nigeria. On the $19^{\text {th }}$ of March, however, it became a necessity for the Federal Government of Nigeria to close down all schools as a precautionary move against the spread of the disease for one month beginning from Monday $23^{\text {rd }}$, but which lasted in the country till further notice. These cost a lot of agonies according to the respondents.

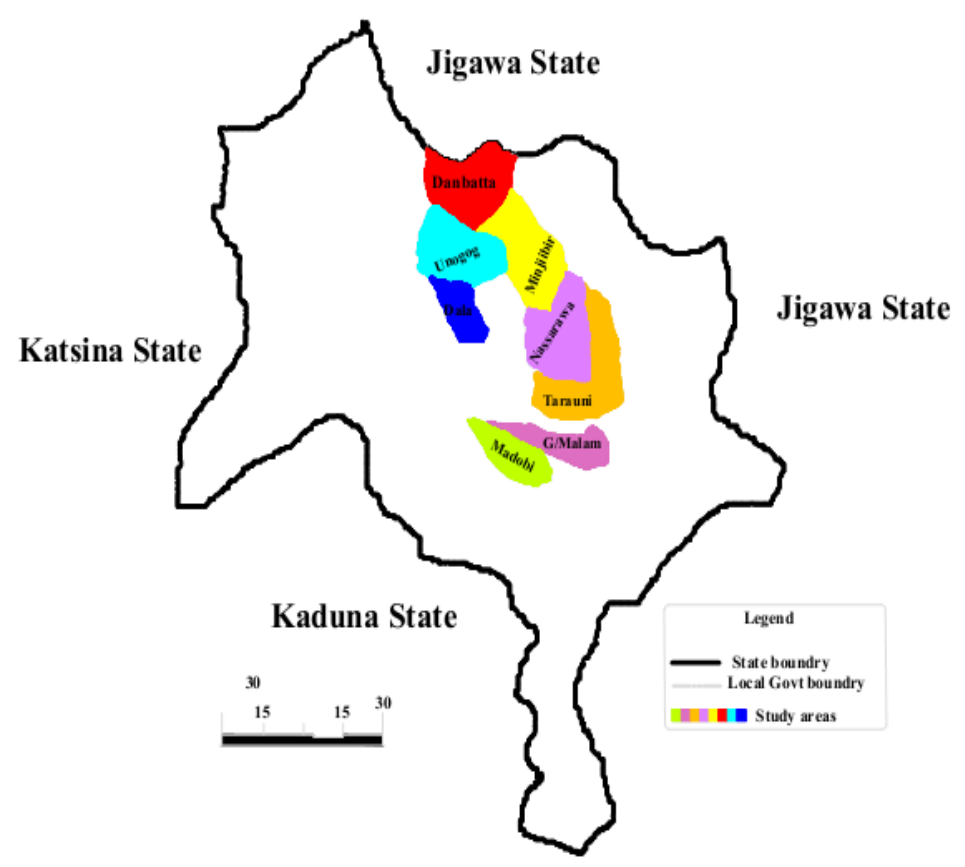

Figure 1 - Map of Kano State showing study areas

Meanwhile, Kano State is a principal architect in the seasonal irrigation and dry season farming which made the state plays a very giant role in the food production program. Nonetheless, with the above trend of events which witnessed the whole country frustratingly shutting down within a week in April, and which was the mid dry season farming period and the month of site preparation that preludes the onset of the rains for the main season agricultural programs, this entire dry-land farming community was put on hold, in view of all official and informal activities, as well as socio-economic and political gatherings went into absolute breakdown, completely halted, including any move for farming activities as corroboratively contained in Egbunike (2020) report.

Within the first seven days of Kano lockdown, the whole metropolitan became completely empty which lasted for over 3 months, while all citizens remained indoors including transporters and those on personal rides (see fig. I). Thereupon, the farmers in the study area covering especially Nassarawa, Tarauni and Dala (LGAs) within the Kano metropolis were locked out of their farms as reiterated in respondent reports. The onset of the lockdown period was however the period of preparation for the main farming season, and the peak of the dry season 
agriculture feasible because of the available irrigation facilities in the state. This was very significant against food production and security as movements were completely under restriction (Egbunike, 2020).

Respondent reports also indicated that chronic hunger persisted within the citizenries across Nigeria during the government policy lockdown, and not only as affected also the dryland farming communities of Kano State. It should be noted that most of these farmers are living a subsistence feeding life, such that the consumption pattern is based on daily provision. Before the Covid-19 logjam, most people have been living a devastated life in view of bad economy, as Nigeria was declared the poverty capital of the world where many lives grossly below the expected income level of $\$ 1.25$ a day. During this lockdown period, the dry-land farmers were unable to get access to basic domestic needs, especially foods. They were exposed to chronic hunger and starvation as most households were facing economic shocks, thereby attempting to adapt and cope with the current realities by adopting coping mechanisms which are liable to have further negative impacts of destruction on them according to the National Bureau of Statistics (NBS) survey, which was further broken down in Adesoji (2020) analysis, corroborating the respondents. These coping mechanisms include reducing food consumption $(51 \%)$ and drawing down of savings (29\%) (Adesoji, 2020). All of these catastrophes capped squarely on the peasant dry-land farmers during the Covid-19 pandemic lockdown endangered the prospect of food production and security for all.

Also revealed through the respondents' reports were the difficulties in the maintenance of agricultural tools and equipments as per those at close proximity to their farms, or those that rather have homestead gardens. This problem specifically hindered the efforts that might have been put in place to sustain the farming activities outside the Kano metropolis under study (Madobi, Minjiibir, Garun Mallam and Dambatta LGAs), where the restriction orders was not as fervent as that of the township. Agricultural tools' mechanics and other service providers who were mostly available in the township were under the lockdown order, and as such, the scenario became one of the hindrances against food security programs in Nigeria as provoked by the pandemic incursion and reiterated on Freedom Radio (2020) to concur with the respondents.

In addition to that, there were gross inability to meet demand on agricultural imputes such as chemicals, fertilizers, machineries, and other tools, equipments and spare parts, as most retailer shops and major marketers were restricted to their homes, thus analyzed on AIT (2020) news report. Additionally, government promises on the provision of these items were also not met at this juncture, which also aggravated the agonies and sufferings of the dry-land farming population in the study area, and consequently increased the encountered difficulties against the farming programs in the country for food security as corroborated in Adesoji (2020) analysis.

Banks and other finance houses were first closed down completely in the first seven days, but when Ramadan fasting approached, they began skeletal services alongside other statutory and public institutions. This is a wide agony of most respondents in the study areas, as this act does not only blocked the chances of getting loans for farming activities, but also deny access to farmers' savings kept for potential use such as site preparation and other cultivation activities in order to enhance food security program for all, starting from the aptitude of individual farmers to ably feed his primary constituency and probably above his family domain. This is reiterated on Freedom Radio (2020) news report in concordance with the respondents. Death

Nigeria lost a number of its cream of the society as well as influential individuals to the novel corona virus pandemic. These include the former Chief of Staff to the President, Mallam Abba Kyari, former Governor of Oyo State, Abiola Ajimobi, former senator of the Federal Republic in Ogun State, Buruji Kashamu, among others. However, in Kano, massive strange deaths were recorded (Fig. III), where tens of corpses were buried every day. Respondents thus revealed that the casualties were no longer faceless individuals as the calamity derailed, but influential people and supporters of positive development programs including agriculture. 
An investigation however by Dr. Zainab Mahmoud, a Kano youth activist put the number at over 100, as shared on Twitter on April $25^{\text {th }} 2020$. That same day, the Nation, a Nigerian daily tweeted a report containing a list of about 20 prominent people who had died in Kano. The report showed that in just three days from April 17 to $19^{\text {th }}$, over 150 people had been buried. Also the Premium Times, another Nigerian online newspaper equally reported about the death of seven Professors in Kano in same April; and on June $8^{\text {th }}$, Nigeria's Health Minister, Dr. Osagie Ehanire confirmed that a surge of mysterious deaths recorded in Kano State was triggered by or due to Covid-19. Ehanire further stated that Kano witnessed 979 fatalities at a rate of 43 deaths per day in April. This was corroborated in Egbunike (2020) report.
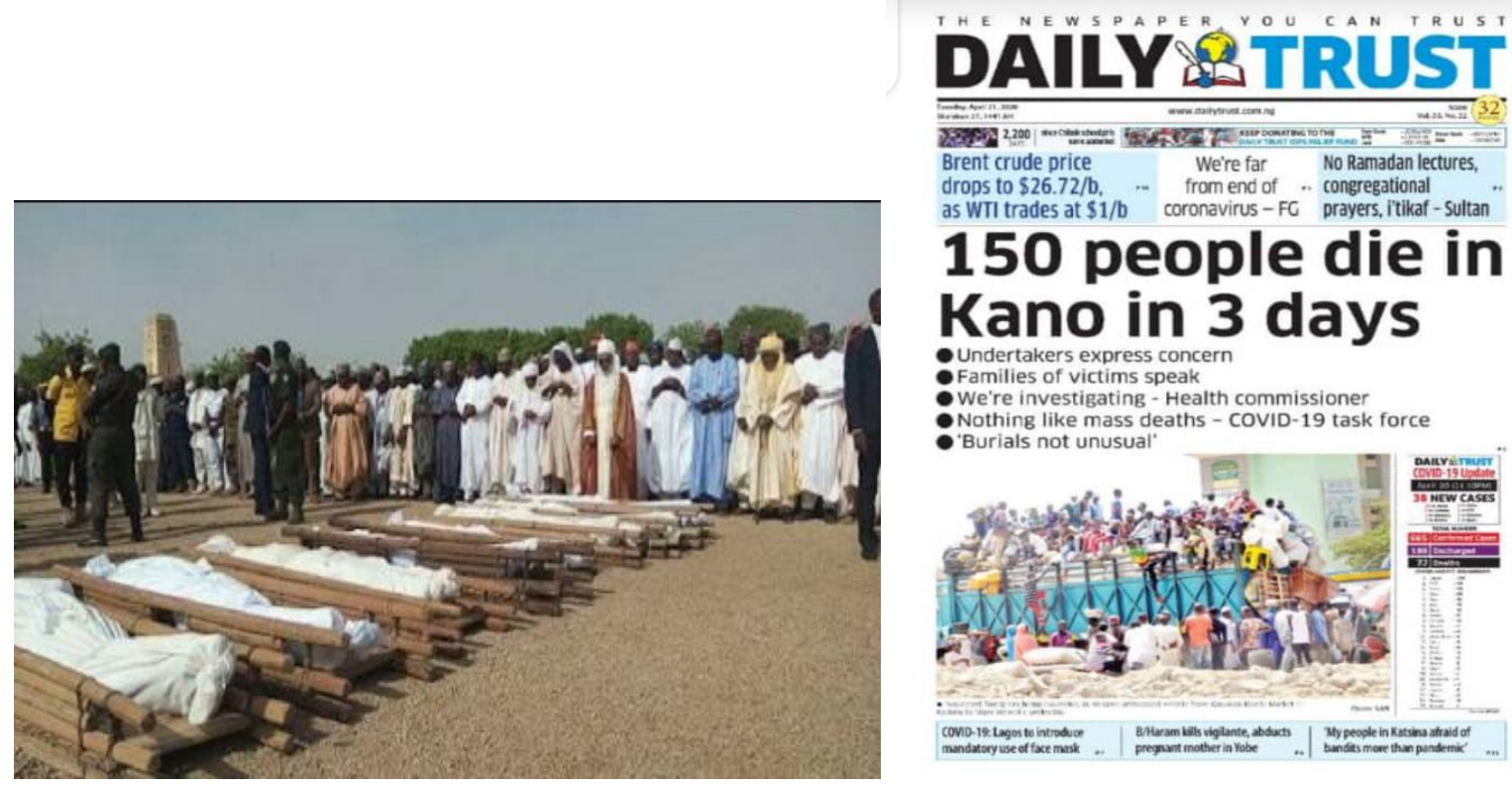

Figure 2 - Colossal Death Indicators in the Kano Metropolis in April, 2020. Insufficient and Decline in Government Statutory Budgets

Data collected from the field across the 8 LGAs within and outside the Kano metropolis further indicated that the farmers were completely down economically with reduced and complete loss of per capita income in view of the Covid-19 pandemic invasion and the subsequent follow up events of lockdown and others. Majorities were completely "empty" financially, as there were no opportunities for any composite or ad hoc activities to boost their drained purse built from the annual farm proceeds. These were already depleted because of the "stay at home" order, amidst the usual fragile and subsistence economy in which they indulge. The fall out trends however followed the economic linkage web chain, as the higher percentages of the populace were peasant farmers who live in mutual co- existence with other occupational sector operators, all of whom were badly affected economically during the "hold on" for loss of jobs, capital base of investments, lack of banking facilities, etc. This is corroborated by the maiden report of the Covid-19 impact monitoring survey recently released by the National Bureau of Statistics (NBS), which indicated that $79 \%$ of respondents had their income diminished, which affected the poorest households from the lowest quintile to the tune of $45 \%$, and the wealthiest households at 35\% as contained in Adesoji (2020) breakdown analysis.

Inflation rate was very apparent during the pick of the ravaging pandemic, as costs of basic amenities were completely outrageous. This was very discouraging to investment, and not the least affected the food production and food security for all in Nigeria. In addition to this, the little resources at the disposal of the affected dry-land farmers were too little to meet the high 
cost of living resulting from the inflationary trends as revealed by the respondents. Also in line with this development, recent data from the National Bureau of Statistics (NBS) according to Oyekanmi (2020) revealed that Nigerian inflation rate increased by $12.34 \%$ (year-on-year) in April, 2020. This is $0.08 \%$ higher than the rate of $12.26 \%$ in March, and the highest rise since April, 2018. In essence, demand and supply shocks to commodity and the fallout from the Covid-19 pandemic was keeping inflation above its long-term rate of $11.9 \%$; and as the country battles with the economic downturn that came with the pandemic, Nigeria's inflation rate hit its highest in 24 months (Proshare, 2020).

Poor management of and the supportive aids to the dry-land farming programs through the inadequate budgetary allocations of the various arms of government in Nigeria to agriculture was highly lamented upon by the respondents. This is in agreement with the reality of which was very paramount to the rude shock they received at the instance of the Covid-19 pandemic. Moreover, the laxities at this regard had being in the gross before the pandemic, which made specialization and enduring occupational activities, a difficulty.

According to the report of Okojie (2020) in consonant with the above, the Federal Government of Nigeria signed the Maputo agreement in the year 2003 to allocate $10 \%$ of its annual budget to the development of agriculture. This was in a bid to promote food security and maximize growth, but the treaty is yet to be implemented 17 years on now. The report further stated that the Federal Government's annual average of $1.4 \%$ budgetary allocation to the agricultural sector has failed to improve farmers' output, as low yield per hectare of most food and cash crops persists in view of low imputes from the government. Nonetheless, the yearly poor budgetary allocations to the sector cannot at the barest minimum address issues relating to mechanization, insurance, research and development among others, which have continued to impact farmers' productivity negatively as enumerated in Okojie (2020) analysis.

In line with the above index report, the Federal Government was compelled amidst the Covid-19 catastrophe to further reduce its annual budget for 2020 with about $2.6 \%$, while Kano and Gombe states dry-lands made 30 and 26.2 percentages respectively, among all other states in the country that did same (Ajakaiye, 2020). With all of these, the food security for all is suffering a great set back, exacerbated by the upsurge of the Covid-19 scenario, while the dryland farmers had the greatest hit, according to field reports.

Not the least is the crime rates which increased tremendously at the event of the Covid-19 catastrophe, and the fear of uncertainties to contain looming fraud in this frustrating period. This however cut down the level of trusts between the dry-land farmer groups and some hopeless nonentities among individuals who indulge in shameful scamming acts according to respondents. As such, the farmers were scared, downtrodden and careful in their deals and bargains because of the agonies of unpredictable betrayal of trust from such collaborations, assistance, or amalgamated socio-economic engagements which could be disastrous, and thus adding more to the miseries already caused by the Covid-19 pandemic.

Owing to the above analytical trends, Nairametrics (2020) indicated that Nigerians are deeply immersed in opportunistic crime schemes very popularly across the globe, and are always prepared to latch on to the uncertainties created by the pandemic to perpetrate new fraud schemes, albeit, with the same underlying principles that have been used over years such as impersonation, spamming, phishing and malware. It was further reiterated in support of the above scenario as Google claimed to have blocked more than 100 million phishing emails daily, and saw about 18 million of those daily mails being related to Covid-19 in the past few months in the year 2020. This was in addition to the more than 240 million daily spamming messages also related to Covid-19, an unfortunate trend indeed for a world economy already in dire straits. With these developments moreover, most banks in Nigeria were always giving their customers some basic informative alerts during the pandemic lockdown and thereafter, to contain and protect them from transactions that may be dangerous for fraud and crime sake (Nairametrics, 2020). 


\section{CONCLUSION}

The Kano State dry-land environment is notable for agrarian activities in the sustenance of the food production and security programs of the Sub-Saharan Africa for sustainable growth and development utilization, owing to its vast land area and enduring irrigation facilities for all the year round agricultural activities. Moreover, the framework for the analysis of food and nutrition security however details the factors responsible for low consumption of food and resulting malnutrition in the developing world. Nonetheless, the socio-economic and political environment at the national and sub national levels of the various governments is more or less the principal determinant of food security prowess since it influences food availability, stability of food supplies; and access to food, which in turn influence the amount of food consumed. When these factors interact with the health and sanitation environment alongside care practices therefore, they determine the nutritional status of the individual.

Basically, it is an intrinsic fact that food insecurity and malnutrition in Nigeria, especially within the rural areas and the urban poor results from the non implementation and/or faulty implementation of the National Food and Nutrition Policy and National Plan of Action for Food and Nutrition. Other reasons identified include low priority for nutrition on the agenda of government, and the resultant poor funding at all levels of governments on agriculture, poor understanding by policymakers of the contents of nutrition programs in relation to other sectors, poor infant and child feeding practices, inadequate access to healthy environment and health services, as well as various care practices, otherwise, there would have been "no cry" at the event of the Covid-19 pandemic and its associated indices as it affects the dry-land farmers of Kano State who are the major stakeholders in the food production and security; not only covering the sovereignty of Nigeria, but also the entire Sub-Saharan-Africa.

\section{RECOMMENDATIONS}

With Nigeria in this critical time of economic pressure and the insurgence of Covid-19 that throw all the nations of the world into chaos, it is very important therefore to have an update account of the coverage at which the situation had carried its weight into our system as regards food security for all, so as to be able to divulge a positive way out working with other global communities. Budget allocations to the agricultural sector should however be improved, while a very serious approach is given to policy improvement and management of the agricultural sector of the economy. This would manifest by giving very compelling priority for nutrition on the agenda of the government, and enforcing a vibrant policy at aiding the dry-land farmers from whom the bulk of the food production activities emanates.

\section{REFERENCES}

1. Adesoji, B.S. (2020): Covid-19: Survey Confirms Job Losses, Hardship for Nigerians. nairametrics.com.

2. AIT (2020): AIT News @ 6. African Independent Television. https://ait.live -14th April, 2020

3. Akinyele, I.O. (2009): Ensuring food and nutrition security in rural Nigeria: An assessment of the challenges, information needs, and analytical capacity. NSSP Working Paper.

4. Asika, N. (2006): Research Methodology in the Behavioral Sciences. Longman Nigeria Plc. p. 45.

5. Atinmo and Adeniran (1999): in: FSP (2012): Food Security Portal: http://www.foodsecurityportal.org/nigeria/resources.

6. Egbunike, N. (2020): The Kano COVID-19 deaths: Stories untold (Part I).

7. FAO (2003): Food and Agricultural Organization, United Nations Trade Reforms and Food Security Conceptualizing the Linkages. 
8. FAO (1996): Rome Declaration on Food Security and World Food Summit Plan Action.

9. Freedom Radio (2020): News at Noon. 99.5 FM-16th April.

10. FSP (2012): Food Security Portal. http://www.foodsecurityportal.org/nigeria/resources.

11. Gary, B.; Mark, N.; Cristofer, P.; William, H.; and J. Cook (2000): Guide to Measuring Household Food Security (PDF). United States Department of Agriculture (USDA) Food and Nutrition Service.

12. IFAD (2012): Annual Report. International Fund for Agricultural Development. Food and Agricultural Organization (FAO) of the United Nations (UN). www.ifad.org.

13. Nairametrics (2020): How thieves use Covid-19 to defraud bank accounts. nairametrics.com

14. Okojie, Josephine (2020): Federal Government's annual 1.4\% agric budget fails to farmers' productivity. businessday.ng.

15. Ojo, E.O. and P.F. Adebayo (2020): Food Security in Nigeria: An Overview.

16. Oyekanmi Samuel (2020): UPDATED: Nigeria's inflation rate rises to $12.34 \%$ as Covid effects bites harder. Nairamatrics. nairamatrics.com.

17. Proshare (2020): Demand and Supply Shocks from Covid-19 keep Inflation Higher for Longer. www.proshareng.com.

18. World Bank (2012) Food Security Portal: http://www.foodsecurityportal.org/nigeria/resources

19. Salami, A.O. (2018): Pre-germination Treatments of some Indigenous Sudan Savannah Tree Species in Nigeria. A Dissertation Report for M.Sc. Award. Department of Geography, Faculty of Earth and Environmental Sciences, Bayero University, Kano. 